\title{
Effect of Perinatal Protein Malnutrition Under Serotonergic Control on Feeding Behavior: A Systematic Review
}

\author{
Rafael Danyllo da Silva Miguel ${ }^{1,}$, , Lisiane dos Santos Oliveira ${ }^{2}$, Sandra Lopes de Souza ${ }^{3}$ \\ ${ }^{1}$ The Program in Neuroscience and Behavioral Sciences of Federal University of Pernambuco, Recife, Brazil \\ ${ }^{2}$ Academic Center of Vitoria of Federal University of Pernambuco, Vitória de Santo Antão, Brazil \\ ${ }^{3}$ Department of Anatomy of Federal University of Pernambuco, Recife, Brazil
}

Email address:

r-danyllo@hotmail.com (R. D. da S. Miguel)

\section{To cite this article:}

Rafael Danyllo da Silva Miguel, Lisiane dos Santos Oliveira, Sandra Lopes de Souza. Effect of Perinatal Protein Malnutrition Under Serotonergic Control on Feeding Behavior: A Systematic Review. International Journal of Nutrition and Food Sciences.

Vol. 4, No. 5, 2015, pp. 584-589. doi: 10.11648/j.ijnfs.20150405.21

\begin{abstract}
Protein malnutrition during the perinatal period leads to several morphological and physiological changes in the central nervous system whose main purpose is to prepare the body for environmental conditions. Several studies have been developed to explain the effects that malnutrition causes over feeding behavior in adults, and in particular on the role of the serotonergic system in this control. Thus, the objective of this systematic review was to assess emerging literature on the effects of perinatal malnutrition on the control of feeding behavior and the role of the serotonergic system in this control. The articles were researched in the virtual libraries Pubmed, Lilacs and Medline using as keywords: "Protein Malnutrition", "Feeding Behavior", "Serotonin Receptors", "Gestational malnutrition", "Perinatal undernutrition", "Fetal Nutrition Disorders" and "Serotonin". 261 articles in total were found. However, after excluding duplicates and analysis of the criteria for inclusion and exclusion 8 articles remained. Analysis of the articles showed that malnutrition in the perinatal period leads to changes in food preference in rats, in addition to delaying the point of satiety of these animals. It was also found that there is increased protein expression of c-fos groups forebrain neurons, increased expression of 5HT-1A receptors and increase in brain serotonin levels. These findings suggest that changes in eating behavior in malnourished animals can be brought about due to changes in the serotonergic system.
\end{abstract}

Keywords: Serotonin, Feeding Behavior, Protein Malnutrition

\section{Introduction}

Early in the life of mammals, there are phases in which intense physiological and structural changes in the nervous system occur, such as neurogenesis, synaptogenesis, and cell migration [1-3]. These phases have been termed critical periods of development [4]. The lack of nutrients during critical periods can promote the development of various types of diseases in the adult individual [5-7]. The main critical periods of development are the period of pregnancy and lactation $[3,8]$.

Studies to identify morphological and physiological changes in adulthood, resulting from assaults during the critical period, found an increase in the incidence of diabetes type II [6], increased visceral adiposity [9], hyperphagia, increased body weight, preference for palatable and high-fat diets, among others [10-12]. Furthermore, malnutrition during pregnancy or during lactation still entail changes in the serotonergic system, such as desensitization of 5HT-1B receptors and increased basal levels of brain serotonin, causing behavioral changes, which highlight the feeding behavior [7,13].

Feeding behavior is a complex mechanism that involves both central and peripheral stimuli that regulate hunger and satiety [14]. Among the various biomolecules that regulate feeding behavior [15], we can highlight some neurotransmitters such as some catecholamines [16-17], serotonin [18-19], Neuropeptide Y (NPY), a peptide related to Agouti (AgRP), Pro-opiomelanocortin (POMC) and Transcript Related to Cocaine and Amphetamine (CART) [20-24]. The different signals from different parts of the body are integrated into the central nervous system at the level of the hypothalamus and brainstem [25-27].

In recent years, several new studies have been conducted in order to associate malnutrition during perinatal period with changes in feeding behavior due to damage to the serotonergic system. Therefore, this study aimed to verify that association 
through a systematic search investigating the publications of the last five years.

\section{Method}

This study deals with a systematic review of the literature. To this end, we selected original articles published in the last five years. The selection of items was held between October 18, 2014 until June 8, 2015 in the virtual libraries Pubmed, Scielo and Medline. The descriptors used were "Protein Malnutrition", "Feeding Behavior", "Serotonin Receptors", "Gestational malnutrition", "Perinatal undernutrition", "Fetal Nutrition Disorders" and "Serotonin".

Among all the articles found, all original ones that correlated malnutrition in the perinatal period with changes in feeding behavior and / or the central serotonergic system published in Portuguese, English or Spanish were included. As the exclusion criteria, we used review articles such as those articles that were published over five years ago and all articles published in languages other than Portuguese, English and Spanish. After application of exclusion and inclusion criteria, the remaining articles were arranged alphabetically for deletion of duplicates and analysis of the main results.

\section{Results}

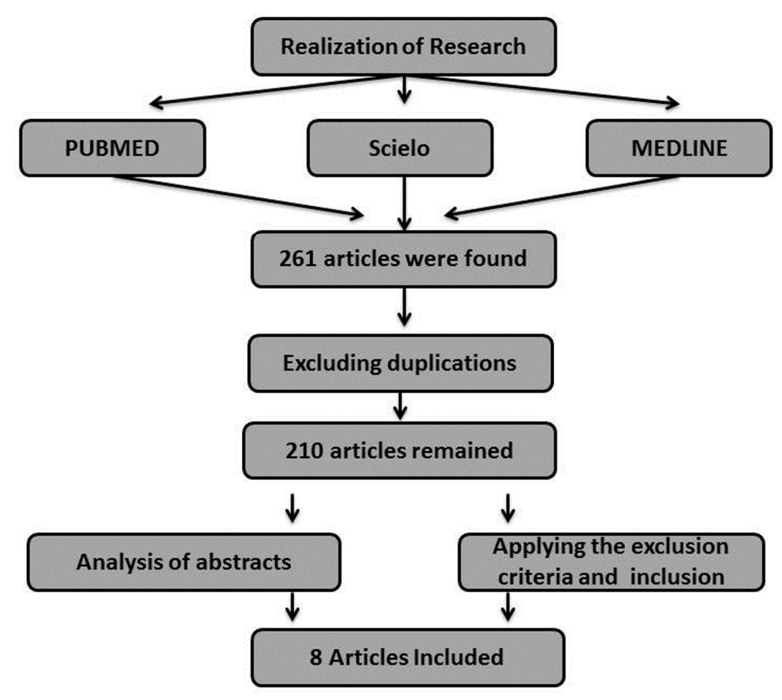

A total of 261 articles were found and distributed in the surveyed virtual libraries, 224 in Pubmed, 7 in Scielo and 30 in Medline. After applying the exclusion criteria and duplications found, eight articles remained. The steps of the review follow in Figure 1.

Table 1 shows the relationship between the set of words used with the number of articles found by the virtual library.

Table 1. Relations between the keywords used and the number of articles obtained by virtual library.

\begin{tabular}{lllll}
\hline & Pubmed & Scielo & Medline & Total \\
\hline $\begin{array}{l}\text { Protein Malnutrition and } \\
\text { Feeding Behavior }\end{array}$ & 93 & 4 & 15 & 107 \\
$\begin{array}{l}\text { Protein Malnutrition and } \\
\text { Serotonin Receptors }\end{array}$ & 2 & 0 & 0 & 2 \\
$\begin{array}{l}\text { Feeding Behavior and } \\
\text { serotonin receptors }\end{array}$ & 99 & 3 & 1 & 95 \\
$\begin{array}{l}\text { Gestational malnutrition and } \\
\text { Feeding Behavior }\end{array}$ & 15 & 0 & 8 & 23 \\
$\begin{array}{l}\text { Perinatal undernutrition and } \\
\text { Feeding Behavior }\end{array}$ & 12 & 0 & 3 & 15 \\
$\begin{array}{l}\text { Fetal Nutrition Disorders and } \\
\text { serotonin }\end{array}$ & 3 & 0 & 3 & 6 \\
$\begin{array}{l}\text { TOTAL } \\
\text { TOTAL After duplications }\end{array}$ & 224 & 7 & 30 & 261 \\
$\begin{array}{l}\text { TOTAL after the exclusion } \\
\text { criteria }\end{array}$ & & & 210 \\
\hline
\end{tabular}

The types of malnutrition used were protein or caloric. Among the eight selected articles, six used the rat as experimental animal, another used a mouse and the last one used sheep. Among the six articles that have been performed in rats, the diets used to promote perinatal protein malnutrition showed variation in the concentration of casein. Thus, the control diet in two studies showed $17 \%$ casein and test diet was formulated with $8 \%$. An article used $20 \%$ and $8 \%$ and another article used $22 \%$ and $0 \%$ casein to the test and control groups respectively. The two other articles used as malnutrition model a food restriction of $50 \%$. This same pattern of $50 \%$ was applied to the study of sheep and another pattern of malnutrition under $40 \%$ of the reference consumed by the control group was used in the article that worked with mice. Articles found, the diets used, their respective objectives and key results are summarized in Table 2.

Figure 1. Flowchart illustrating the steps of review.

Table 2. Main relevant aspects of the articles analyzed.

\begin{tabular}{|c|c|c|c|c|}
\hline Authors & Kind & Goals & $\begin{array}{l}\text { Type of malnutrition / } \\
\text { period }\end{array}$ & Main Results \\
\hline Orozco-Solis et al., 2009 & Rats & $\begin{array}{l}\text { Analyze the feeding behavior of } \\
\text { malnourished rats in the perinatal } \\
\text { period }\end{array}$ & $\begin{array}{l}\text { Protein malnutrition. Diet with } \\
20 \% \text { casein for the control } \\
\text { group and } 8 \% \text { for the } \\
\text { malnourished rats in the } \\
\text { perinatal period. }\end{array}$ & $\begin{array}{l}\text { During the first weeks after weaning } \\
\text { malnourished pups had higher food } \\
\text { consumption than the control group. } \\
\text { Furthermore, it was found that malnourished } \\
\text { animals had an increase in the size of meals } \\
\text { and not increasing the number of meals. }\end{array}$ \\
\hline $\begin{array}{l}\text { Manjarrez-Gutiérrez et } \\
\text { al., } 2012\end{array}$ & Rats & $\begin{array}{l}\text { Check that intrauterine malnutrition } \\
\text { can alter the tryptophan hydroxylase } \\
\text { I and II expression to explain the } \\
\text { accelerated serotonin synthesis seen }\end{array}$ & $\begin{array}{l}\text { Calorie malnutrition. Standard } \\
\text { diet for rats was administered } \\
\text { in the control group and other } \\
\text { diet with } 50 \% \text { of the standard }\end{array}$ & $\begin{array}{l}\text { The intrauterine malnutrition increases the } \\
\text { trunk brain serotonin levels such as increased } \\
\text { expression of tryptophan hydroxylase I and } \\
\text { reduces the expression of }\end{array}$ \\
\hline
\end{tabular}




\begin{tabular}{|c|c|c|c|c|}
\hline Authors & Kind & Goals & $\begin{array}{l}\text { Type of malnutrition / } \\
\text { period }\end{array}$ & Main Results \\
\hline & & in malnourished animals. & $\begin{array}{l}\text { nutrient was administered in } \\
\text { the malnourished group }\end{array}$ & tryptophan-hydroxylase II. \\
\hline da Silva et al., 2013 & Rats & $\begin{array}{l}\text { Analyze the effects of protein } \\
\text { malnutrition in the period of } \\
\text { pregnancy and lactation on s } \\
\text { neurobiological mechanisms of food } \\
\text { reward. }\end{array}$ & $\begin{array}{l}\text { Diet with } 17 \% \text { casein for the } \\
\text { control group and } 8 \% \text { for the } \\
\text { malnourished group. }\end{array}$ & $\begin{array}{l}\text { The protein malnutrition increases motivation } \\
\text { for food reward and increases the protein } \\
\text { expression of c-Fos in neurons in the } \\
\text { basolateral amygdala and core, putamen, } \\
\text { caudate nucleus, and dorsomedial nucleus of } \\
\text { the hypothalamus. }\end{array}$ \\
\hline Lira et al., 2014 & Rats & $\begin{array}{l}\text { Analyze the effects of perinatal } \\
\text { malnutrition on the activation of the } \\
\text { nucleus of the solitary tract in rats in } \\
\text { response to food stimulation. }\end{array}$ & $\begin{array}{l}\text { Diet with } 17 \% \text { casein for the } \\
\text { control group and } 8 \% \text { for the } \\
\text { malnourished group. }\end{array}$ & $\begin{array}{l}\text { Animals that have suffered perinatal } \\
\text { malnutrition had higher feed intake and } \\
\text { increased activation of NTS in response to } \\
\text { food stimuli }\end{array}$ \\
\hline Rocha et al., 2014 & Rats & $\begin{array}{l}\text { Study the system } \\
\text { ARC, PVN, and during NPY } \\
\text { development of hypothalamic nuclei }\end{array}$ & $\begin{array}{l}\text { Diet with } 22 \% \text { protein for the } \\
\text { control group and } 0 \% \text { for the } \\
\text { malnourished animals. }\end{array}$ & $\begin{array}{l}\text { Protein malnutrition causes a delay in the } \\
\text { distribution of NPY in the arcuate } \\
\text { paraventricular-administration in rats. }\end{array}$ \\
\hline $\begin{array}{l}\text { Manuel-Apolina et al., } \\
2014\end{array}$ & Rats & $\begin{array}{l}\text { Analyze the effects of intrauterine } \\
\text { malnutrition on the expression of } \\
\text { 5HT-1A receptors, D1 and D2, and } \\
\text { Ob-Rb }\end{array}$ & $\begin{array}{l}\text { Standard diet for rats was } \\
\text { administered in the control } \\
\text { group and other diet with } 50 \% \\
\text { of the standard nutrient was } \\
\text { administered in the } \\
\text { malnourished group }\end{array}$ & $\begin{array}{l}\text { An increase in the expression of } 5 \mathrm{HT}-1 \mathrm{~A} \\
\text { receptor and } \mathrm{D} 2 \text { on day } 14 \text {, and Ob-Rb on day } \\
14 \text { and } 90 \text {. There was a decrease in D1 } \\
\text { receptor expression in the hypothalamic } \\
\text { nuclei on the } 14 \text { th day and increased on the } \\
90 \text { th day. }\end{array}$ \\
\hline Avraham et al., 2010 & Mice & $\begin{array}{l}\text { Examine whether supplementation } \\
\text { with fish oil better morbidity and } \\
\text { mortality associated with } \\
\text { malnutrition and normalize } \\
\text { endocannabinoids and } \\
\text { monoaminergic systems involved in } \\
\text { satiety and cognitive function in the } \\
\text { hypothalamus and hippocampus }\end{array}$ & $\begin{array}{l}\text { Standard diet to mice was } \\
\text { administered in the control } \\
\text { group and other diet with } 40 \% \\
\text { of the standard nutrient was } \\
\text { administered in the } \\
\text { malnourished group }\end{array}$ & $\begin{array}{l}\text { The fish oil supplement with increased } \\
\text { lifetime and reduced cognitive decline in } \\
\text { animals. In addition, it increased the levels of } \\
\text { expression of genes for serotonin and } \\
\text { dopamine in the malnourished group. }\end{array}$ \\
\hline Nielsen et al., 2013 & Sheep & $\begin{array}{l}\text { Check that malnutrition in late } \\
\text { pregnancy program to increase } \\
\text { appetite and preference for high-fat } \\
\text { foods in postnatal life. }\end{array}$ & $\begin{array}{l}\text { Food standard (commercial } \\
\text { plus) for the control group and } \\
\text { sheep for the group test } \\
\text { another diet with } 50 \% \text { of the } \\
\text { standard diet of nutrients. }\end{array}$ & $\begin{array}{l}\text { Malnourished sheep exhibit hyperphagia and } \\
\text { preference for fatty and caloric foods. }\end{array}$ \\
\hline
\end{tabular}

\section{Discussions}

Several previous studies have correlated malnutrition in the perinatal period with permanent changes in different regions of the nervous system. The main findings suggest that malnourished animals show changes in the normal synthesis of serotonin and the identification of the biomolecule by their respective receptors $[1,18,28]$. Thus, the behavior in general, reflects the damage, whose principal behaviors affected are aggression [29], learning [30] and feeding behavior [13]. Feeding behavior is the result of interactions influenced by various central and peripheral stimuli that govern the search for food and hunger and satiety mechanisms [14]. This systematic review strengthens the literature, intensifying the hypothesis that the changes found in feeding behavior in early malnourished animals are due to changes in the serotonergic system.

Experimental studies with behavioral sequence of satiety in malnourished animals in the perinatal period have shown changes in eating behavior in adulthood, which led to increasing the size of the meal [7, 31]. The analysis of graphs of behavioral satiety sequence showed that malnourished animals showed a delay in satiety point, which consequently leads these animals to consume more food [7, 31], as shown in Figure 1. Similar results to these can be found in other previous studies, which have also undergone animals to protein malnutrition and found this delay in satiety [32-34].

Besides increasing the size of the meals, it was also observed that the protein malnutrition in the perinatal period leads to increased motivation for food reward and preference for palatable and rich-in-fat diets, in which these findings were observed in rats and sheep $[9,30]$. The hedonic control of feeding behavior is regulated by different brain areas, such as the limbic system [35], cingulate and orbitofrontal cortex, mainly mediated by dopamine [36] and Serotonin [37]. Among these brain structures, the amygdala, caudate nucleus and the hypothalamus are involved in particular events related to the search for food reward. Therefore, besides investigating the motivation palatable food, da Silva and colleagues (2013) investigated the neuronal activation of undernourished rats in response to palatable food stimulus [30]. As a result, they observed increased neuronal activation in the basolateral amygdala and central core, putamen, caudate, and dorsomedial nucleus of the hypothalamus. These data seem to be in accordance with modifications of the motivation for palatable food intake.

Once the behavioral changes involved in food and food reward search may be triggered mainly by molecular modifications of dopaminergic and serotonergic pathways, it was found that in malnourished animals there was an increase 
in gene expression for the 5HT-1A receptor such as an increase in serotonin levels and tryptophan hydroxylase I $[28,38]$. The 5HT-1A receptors are important receptors in satiety mechanism [39]. Studies show that stimulation of these receptors in the paraventricular nucleus of the hypothalamus

A

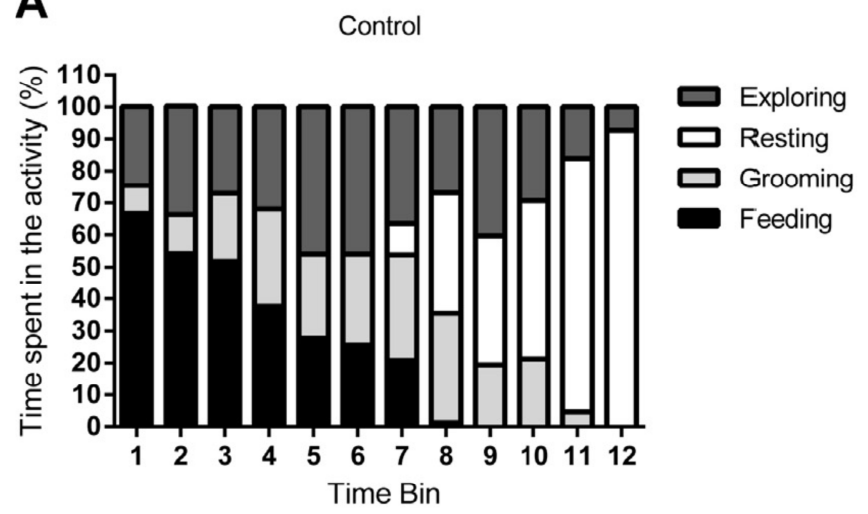

C

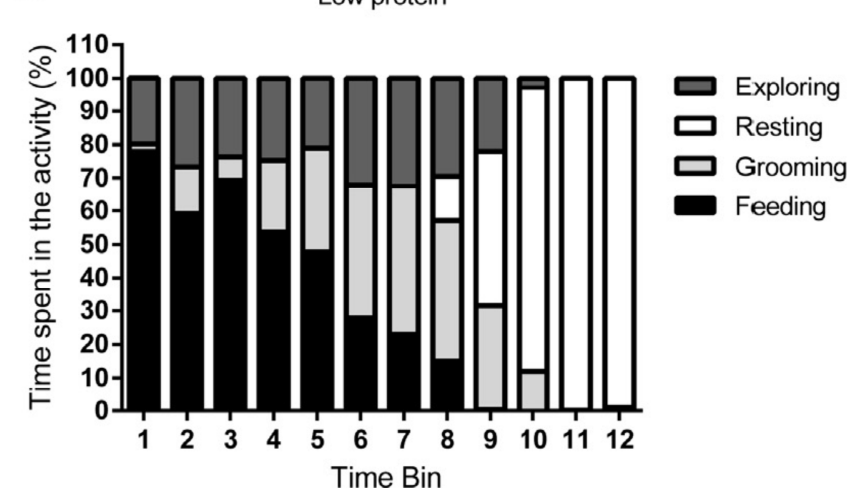

reduces appetite, leading to satiety [18]. An increase of the number of these receptors associated with increased serotonin levels found suggests that there was a desensitization of the 5HT-1A receptors, since these animals showed a delay in satiety point [13].
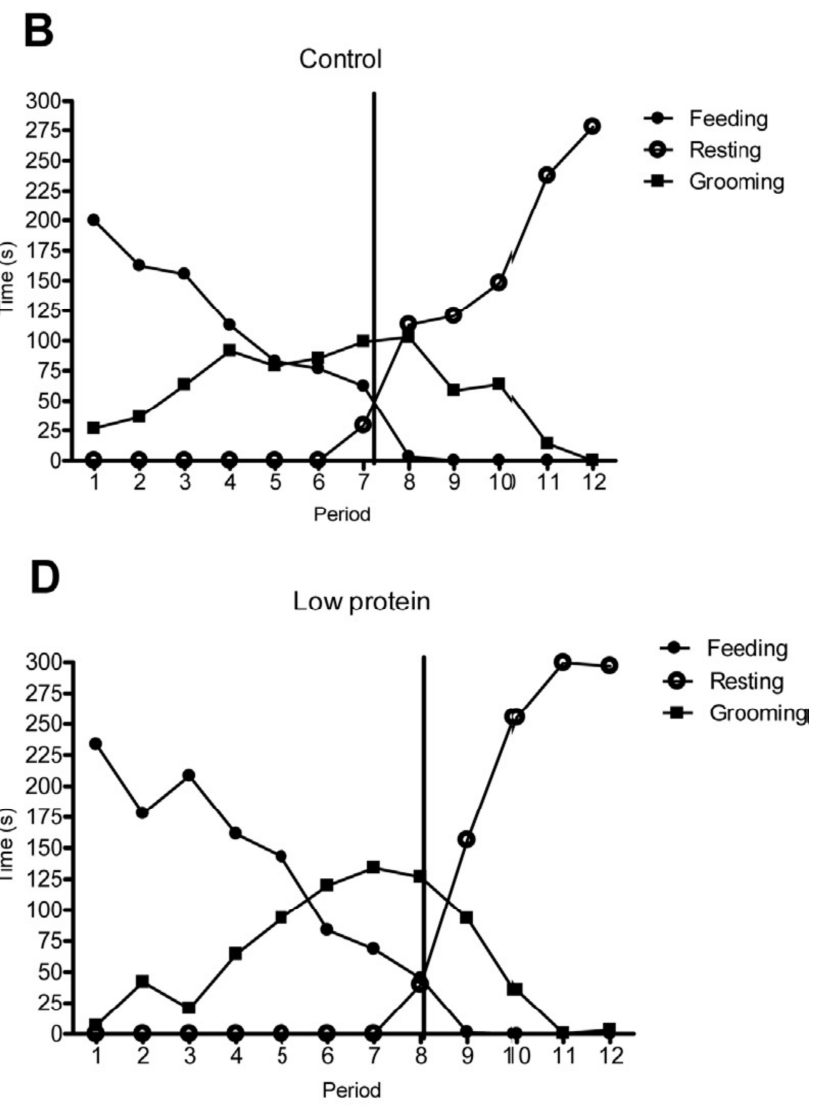

Figure 2. Sequence of behavioral satiety in animals for 150 days old, subjected to perinatal malnutrition. (A) and (C) Power-supply frequency is not conduct in each period (5 min / period). (B) and (D) graphics that illustrate the crossing point between feeding behavior and rest. The vertical line indicates the point of satiety. (Lira, Almeida et al., 2014).

Among the various biomolecules related to feeding behavior, there is Neuropeptide Y. Rocha et al (2014) verified that total protein malnutrition in the perinatal period leads in delayed maturation of the path of the arcuate NPY to the paraventricular nucleus, although it has not been consolidated the consequences of this event on feeding behavior [43].This neuropeptide is synthesized mainly by neurons in the arcuate nucleus of the hypothalamus. These neurons, when stimulated, cause starvation in animals [40]. An important receptor for regulating the release mechanism of NPY is the $5 \mathrm{HT}-1 \mathrm{~B}$ receptor, which inhibits their synthesis. It is a presynaptic receptor expressed in various regions of the central nervous system, such as the hippocampus, cingulate gyrus, raphe nuclei and hypothalamic regions that govern feeding behavior, such as the paraventricular and ventromedial nucleus.

Another area affected by protein malnutrition in the perinatal period and that is also related to feeding behavior was the Nucleus of the Solitary Tract. It was verified that the NTS shows more activity in response to food in malnourished animals compared to the control group [31]. The NTS neurons receive information through various biomolecules and send dense projections to the lateral hypothalamus, taking action similar to electrical stimulation of the paraventricular nucleus of the hypothalamus [41-42]. It is noteworthy that the NTS receives afferents both from the gustatory pathways and from gastrointestinal neural pathways, which shows its importance in feeding behavior.

The damage that malnutrition causes in the serotonergic system, besides directly affecting the feeding behavior, causes impairment in memory mechanisms behavior [30]. This study verified through a food-motivational test that malnutrition interferes with the reward once the animal has a delay in storing the location of palatable food. This may happen due to the fact that malnutrition early in life affects the hippocampal formation [30]. Knowing that cognitive decline, Avraham et al (2010) developed a study with the purpose to check if the use of fish oil could reduce cognitive decline and normalize satiety signals evoked by serotonin and dopamine that malnourished mice present [44]. Therewith, it was found that the use of this oil not only reduces the cognitive decline and normalizes satiety signals but also increases the lifetime of animals. These findings, among others found in this review, deserve special 
mention because it suggests that some of the effects observed due to malnutrition in the perinatal period can be mitigated.

\section{Conclusions}

Protein malnutrition in the perinatal period can promote changes in the control mechanisms of feeding behavior, including the serotonergic control. Such damage may involve hypothalamic nuclei, nucleus of the solitary tract, striatum, hippocampus, including other brain areas. Malnourished animals in the perinatal period have a higher consumption of pattern diet and increased motivation for food reward.

\section{References}

[1] Morgane PJ, Austin-Lafrance R, Bronzino J, Tonkiss J, Díaz-Cintra S, Cintra L, Kemper T, Galler JR. Prenatal malnutrition and development of the brain. Neurosci Biobehav Rev. 1993; 17 (1): 91-128.

[2] Dobbing J. The Influence of Early Nutrition on the Development and Myelination of the Brain. Proc R Soc Lond B Biol Sci. 1964; 159:503-9.

[3] Winick M, Rosso P, Brasel JA. Malnutrition and cellular growth in the brain. Bibl Nutr Dieta. 1972; (17):60-8.

[4] Matsui F, Morimoto M, Yoshimoto K, Nakatomi Y, Syoji H, Nishimura A, Isoda K, Tanda K, Hosoi H. Effects of stress of postnatal development on corticosterone, serotonin and behavioral changes. Brain Dev. 2009.

[5] Ravelli GP, Stein AZ, Susser MW. Obesity in young men after famine exposure in utero and early infancy. N Engl J Med.1976; 295 (7): 349-53.

[6] Hale CN and Barker D J. The thrifty phenotype hypothesis. Br Med Bull. 2001; 60: 5-20.

[7] Orozco-Solis R, Lopes de Souza S, Barbosa Matos RJ, Grit I, Le Bloch J, Nguyen P, Manhaes de Castro $R$ and Bolanos-Jimenez F. Perinatal undernutrition-induced obesity is independent of the developmental programming of feeding. Physiol Behav. 2009; 96:481-492.

[8] Kikusui T; Kiyokawa Y; Moti Y. Deprivation of mother-pup interaction by early weaning alters myelin formation in male, but not female, ICR mice. Brain Research. 2007; 1133: 115122.

[9] Nielsen MO, Kogsted AH, Thygesen MP, Strathe AB, Caddy S, Quistorff B, Jorgensen W, Christensen VG, Husted S, Chwalibog A, Sejrsen K, Purup S, Svalastoga E, McEvoy FJ, Johnsen L. Late gestacion undernutrition can presispose for visceral adiposity by altering fat distribuition patterns and increasing the preference for a higth-fat diet in early postnatal life. Br J Nutri. 2013; 109 (11): 2098-110.

[10] Vicente LL, De Moura EG, Lisboa PC, Monte Alto Costa A, Amadeu T, Mandarim-de-Lacerda CA, Passos MC. Malnutrition during lactation in rats is associated with higher expression of leptin receptor in the pituitary of adult offspring. Nutrition. 2004; 20(10): 924-8.

[11] Lisboa PC, Fagundes AT, et al. Neonatal low-protein diet changes deiodinase activities and pituitary TSH response to
TRH in adult rats. Exp Biol Med (Maywood). 2008; 233 (1): 57-63.

[12] Erhuma A, Bellinger L, Langley-Evans SC, Bennett AJ. Prenatal exposure to undernutrition and programming of responses to hight-fat feeding in the rat. Br J Nutr. 2007; 98, 517-524.

[13] Lopes de Souza S, Orozco-Solis R, Grit I, Manhães de Castro R, Bolaños-Jiménez. Perinatal protein restriction reduces the inhibitory action of serotonin on food intake. European Journal of Neuroscience. 2008; 27: 1400-1408.

[14] Nagase H, Nakajima A. Regulation of feeding behavior, gastric emptying, and sympathetic nerve activity to interscapular brown adipose tissue by galanin and enterostatin: the involvement of vagal-central nervous system interactions. Journal Gastroenterol. 2002; 37:118-27.

[15] Valassi E, Scacchi M, Cavagnini F. Neuroendocrine control of food intake. Nutr Metab Cardiovasc Dis. 2008; 18 (2): 158-68.

[16] Wellman PJ, Miller DK, Ho DH. Noradrenergic modulation of ephedrine-induced hypophagia. Synapse. 2003; 48 (1):18-24.

[17] Maidel S, Lucinda AM, de Aquino VW, Faria MS, Paschoalini MA.. The adrenaline microinjection into the median raphe nucleus induced hypophagic effect in rats submitted to food restriction regimen. Neurosci Lett. 2007; 422 (2): 123-7.

[18] Lopez-Alonso VE, Mancilla-Diaz JM, Rito-Domingo M, González-Hernández B, Escartín-Pérez RE.. The effects of 5-HT1A and 5-HT2C receptor agonists on behavioral satiety sequence in rats. Neurosci Lett. 2007; 416 (3): 285-8.

[19] Tanaka M e Kido Y. Serotonergic regulation of galanin-induced selective macronutrient intake in self-selecting rats. J Med Invest. 2008; 55 (3):196-203.

[20] Ramos EJ, Meguid MM, Campos AC, Coelho JC. Neuropeptide Y, alpha-melanocyte-stimulating hormone, and monoamines in food intake regulation. Nutrition. $2005 ; 21(2)$ : $269-79$.

[21] Mahaut SY. Dumont, Fournier A, Quirion R, Moyse E. Neuropeptide Y receptor subtypes in the dorsal vagal complex under acute feeding adaptation in the adult rat. Neuropeptides. $2010 ; 44$ (2) :77-86.

[22] Katsuki A, Sumida Y, Gabazza EC, Murashima S, Tanaka T, Furuta M, Araki-Sasaki R, Hori Y, Nakatani K, Yano Y, Adachi Y. Plasma levels of agouti-related protein are increased in obese men. J Clin Endocrinol Metab. 2001; 86 (5):1921-4.

[23] Aja, S. S., Ladenheim, E. E., Schwartz, G. J., Moran, T. H. (2001). Intracerebroventricular CART peptide reduces food intake and alters motor behavior at a hindbrain site. Am J Physiol Regul Integr Comp Physiol. 281 (6), 862-7.

[24] Millington, G. W. The role of proopiomelanocortin (POMC) neurones in feeding behaviour. Nutr Metab (Lond). 2007; 4.

[25] Blevins JE, Baskin DG. Hypothalamic-brainstem circuits controlling eating. Forum Nutr. 2010; 63:133-40.

[26] Blevins JE, Schwartz MW, Baskin DG. Peptide signals regulating food intake and energy homeostasis. Can J Physiol Pharmacol. 2002; 80 (5): 396-406.

[27] Funahashi H, Takenoya F, Guan JL, Kageyama H, Yada T, Shioda S. Hypothalamic neuronal networks and feeding-related peptides involved in the regulation of feeding. Anat Sci Int. 2003; 78 (3): 123-38. 
[28] Manjarrez-Gutierrez G, Martinez-Radilla K, Boyzo-Montes de Oca A, Orozco Suárez S, Hernández-Rodríguez J. Increased expression of tryptophan-5-hydroxylase 1, but not 2, in brainstem as a result of intrauterine malnutrition. Int $\mathbf{J}$ Dev Neurosci.2012; 30 (6): 445-50.

[29] Coccaro EF, Fanning JR, Phan KL, Lee R. Serotonin and impulsive aggression. CNS Spectrum.v. 20, p.295-302, 2015.

[30] Da Silva AA, Borba TK, de Almeida Lira L, Cavalcante TC, de Freitas MF, Leandro CG, do Nascimento E, de Souza SL. Perinatal undernutrition stimulates seeking food reward. Int $\mathrm{J}$ Dev Neurosci. 2013; 31 (5): 334-41.

[31] Lira LA, Almeida LC, da Silva AA, Cavalcante TC, de Melo DD, de Souza JA, Campina RC, de Souza SL. Perinatal undernutrition increases meal size and neuronal activation of the nucleus of the solitary tract in response to feeding stimulation in adult rats. Int J Dev Neurosci. 2014; 38: 23-9.

[32] Vickers MH, Breier BH, Cutfield WS, Hofman PL \& Gluckman PD. Fetal origins of hyperphagia, obesity, and hypertension and postnatal amplification by hypercaloric nutrition. Am. J. Physiol. Endocrinol. Metab. 2000; 279: 83-87.

[33] Bellinger L, Sculley DV \& Langley-Evans SC. Exposure to undernutrition in fetal life determines fat distribution, locomotor activity and food intake in ageing rats. Int. J. Obes. 2006; 30: 729-738.

[34] Desai M, Gayle D, Babu J \& Ross MG. Programmed obesity in intrauterine growth-restricted newborns: modulation by newborn nutrition. Am. J. Physiol. Regul. Integr. Comp. Physiol. 2005; 288:91-96.

[35] Berridge KC, Kringelbach ML. Affective neuroscience of pleasure: reward in humans and animals. Psychopharmacology. 2008; 199 (3), 457-480.

[36] Barbano, M. F., Le Saux M., Cador, M. (2009) Involvement of dopamine and opioids in the motivation to eat: influence of palatability, homeostatic state, and behavioral paradigms. Psychopharmacology. 203 (3), 475-487
[37] Pratt WE, Blackstone K, Connolly ME, Skelly MJ. Selective serotonin receptor stimulation of the medial nucleus accumbens causes differential effects on food intake and locomotion. Behavioral Neuroscience. 2009; 123 (5): 10461057

[38] Manuel-Apolina L, Rocha L, Damasio L, Tesoro-Cruz E, Zarate A. Role of prenatal undernutrition in the expression of serotonin, dopamine and leptin receptors in adult mice: Implications of food intake. Mol Med Rep. 2014; 9 (2): 407-12.

[39] De Vry J, Schreiber R. Effects of selected serotonin 5-HT1 and 5-HT2recep-tor agonists on feeding behavior: possible mechanisms of action. NeurosciBiobehav Rev 2000; 24:34153 .

[40] Cowley MA, Smart JL, Rubinstein M, Cerdan MG, Diano S, Horvath TL, Cone RD, Low MJ (2001) Lepitin activates anorexigenic POMC neurons through a neural network in the arcute nucleus. Nature 411:480-484.

[41] Leibowitz SF, Alexander JT. Hypothalamic serotonin in control of eating behavior, meal size, and body weight. Biol Psychiatry. 1998; 44: 851-864.

[42] Rogers RC, Hermann GE. Vagal afferent stimulation-evoked gastric secretion suppressed by paraventricular nucleus lesion. J Auton Nerv Syst. 1985; 13: 191-199

[43] Rocha MLM, Fernandes PP, Loyufo BM, Manhães AC, Barradas PC, Tenório F. Undernutrition during early life alters neuropeptide y distribution along the arcuate/paraventricular pathway. Neuroscience. 2014, 379-391.

[44] Avraham, Y., Saidian, M., Burston, J. J., Mevorach. R., Vorobiev, L., Magen, I., Kunkes, E., Borges, B., Lichtman, A. H., Berry, E. M. (2010). Fish oil Promotes survival and protects against cognitive decline in severely undernourished mice by normalizing satiety signals. The Journal of Nutritional Biochemistry. 22, 766-76. 